\title{
The Conservation Programme of the Côa Valley Archaeological Park: Philosophy, Objectives and Action
}

\author{
António Pedro Batarda Fernandes
}

This paper outlines the methodology for the conservation of Côa Valley rock art, as carried out by the Côa Valley Archaeological Park Conservation Programme. It examines the overall conservation environment that has determined this approach, which aims at an understanding of all the factors affecting the survival of the Côa Valley heritage. We stress that although the Programme sets precise guidelines for the examination and testing of conservation work to mitigate the effects of complex weathering dynamics in action, there are no miraculous solutions to ensure the complete longterm in situ preservation of this World Heritage Site. Despite this geological impossibility, we also emphasize that in a human time scale it makes sense to try to conserve significant heritage (such as the Côa Valley rock art) that expounds and explains our history and ourselves.

'The day when a statue is finished is, to some extent, the day when its life begins. The first phase in which, thanks to the sculptor's hand, it has changed from block to human shape is closed. In another stage, throughout the centuries, adoration, admiration, love, contempt or indifference will alternate, in successive degrees of erosion and weathering, until it reaches, progressively, the state of shapeless mineral from which the sculptor had taken it.'

(Marguerite Yourcenar (no date) 49, author's translation.)

'Unfortunately the list of negative interactions between applied products, object and environment is vast. To this we must add all the circumstances in which the interactions are unknown. Few studies have devoted their efforts to these matters, which in itself indicates the preferred field of research in rock art conservation.

We may therefore say that, at least when dealing with prehistoric art, active interventions must be considered as the exception.' (Carrera Ramírez 2002, I5, author's translation.) 


\section{Introduction}

Since 2000 we have been developing and coordinating a conservation project for Côa Valley rock art. This project aims to understand, monitor and prevent the effects that could influence the stability of the rocky outcrops, with rock art motifs primarily dating from the Upper Palaeolithic. The rock art corpus in the basin of the lower Côa is one of the most important archaeological and artistic heritage sites in Portugal. It contributes to the development of local tourism (and consequently of the regional economy), job creation, culture as a whole, archaeological research, and the study of human evolution, as well as raising the profile of the region and the country internationally. This irreplaceable archaeological heritage exists in a delicate balance with its surrounding environment. However, little was known about the endogenous and exogenous dynamics - geological, biological or mechanical - that affect its preservation. Hence it was necessary to establish a programme to address holistically the interdependent issues of preservation, conservation and management. To preserve is to manage, to divulge is to preserve, successively and reciprocally.

The legal process of the creation of the Côa Valley Archaeological Park (PAVC) (see Pau-Preto and Luís 2003), only recently initiated, required the preparation of a specific Conservation Programme (Fernandes 2002). This set out the strategic options for the preservation of Côa rock art, and established essential guidelines and conservation management philosophy. These guidelines, published in the document Criação do Parque Arqueológico do Vale do Côa (Creation of the Côa Valley Archaeological Park) (Cabral and Coelho 2002), have been conceptualized and put into practice over the last few years. After completing this Programme, however, we realized that much had been left unsaid, due to the necessary succinctness of such a document. We are taking this opportunity, therefore, to expand the discussion and to present a detailed justification of the Conservation Programme.

\section{Preliminary considerations}

\section{Conservation management philosophy}

After the extended controversy that surrounded the decision to protect and preserve Côa Valley rock art, at the expense of a dam that was being built near the mouth of the River Côa, the major battle to be won today is the survival of this heritage in its landscape. The PAVC was created with the precise mission of managing, organizing for public visits, and protecting Côa Valley rock art.

The conservation of this art has two distinct features - active and preventive both of which play a part in the final goal of averting the various processes of alteration of the rock art 'object'. By active conservation we mean the attempt to retard the development of all the active dynamics that, directly or indirectly, affect the conservation state of the rock art. It also aims to reconcile our desire to preserve the engraved surfaces unaltered, belonging to a conceptual and immutable time, with the action of the regular alteration dynamics of a 'natural' world in constant re-equilibrium. Hence, in this context, a philosophy of active conservation does not aspire to arrest time and its consequences, but to be a realistic effort to harmonize the will of human memory with the will of nature. So, for us, active conservation 
goes beyond mere intervention in the object itself, the engraved panels. All the weathering agents at work in the environmental context that surrounds the engraved outcrops actively contribute to the physical alteration processes and therefore they should be more than simply monitored and controlled: their consequences, as well as their origins, must be addressed systematically, to try to avoid their negative influence on the conservation condition of the engraved outcrops. If we deal with the alteration processes seen in the area surrounding the outcrops, we often avoid operating on the object itself, therefore helping to mitigate, if not the causes, at least the destructive effects of these processes.

We understand preventive conservation as a set of efforts to ensure that the public presentation of the rock art, and everyday land use, will not lead to increased negative impacts from the dynamics mentioned above. Therefore, it was fundamental to implement a restricted public access system (Fernandes 2003). Visitors, even in small numbers, pose preservation problems and thus the negative impact of their presence has to be kept to a minimum, while still giving the general public the chance to visit and appreciate these unique heritage sites. The concept of conservation is therefore understood in the broadest sense possible. The object, the crux of the conservation efforts in the Côa Valley, is not only the engraved surface itself, but also the 'wholeness' that derives from its context (geology, topography, geomorphology, etc.). This context helps our understanding of the significance of Côa rock art substantially, and at the same time is vital in understanding and identifying the weathering processes caused by the dynamics mentioned above. These key features are fundamental in establishing a Conservation Programme that addresses the conservation challenges of Côa rock art effectively.

\section{General context}

The PAVC is situated in north-eastern Portugal, in an area with several frontiers, including the border with Spain, but also the administrative, regional, natural and socio-economic divisions between the provinces of Beira Alta and Trás-os-Montes e Alto Douro (Figure I).

Geomorphologically, the PAVC area is part of the northern extremity of the Iberian Meseta and of the hydrographical basin of the Douro. This region's climatic, morphological and topographic attributes include schist bedrock, poor agricultural soils, low annual rainfall and a dry warm climate, especially in the low-lying riverside areas where temperatures can reach $50^{\circ} \mathrm{C}$ in high summer (Aubry et al. 2002a). Adapted to these harsh conditions, over the last two millennia, was the establishment of a model of land exploitation based on three major monocultures (olives, almonds, and wine), complemented by sheep-farming. The inaccessibility of some riverside areas, and the hard work needed to cultivate the steep slopes, has meant that human activity in these zones has been largely non-intrusive (Figure 2). This is probably the reason for the survival of many of the rock art motifs. By I998, twenty-eight rock art sites, with more than I,200 individual motifs on approximately two hundred different rocky surfaces, had been identified (Baptista I999). Today this number has risen to some 6,000 motifs and 600 engraved outcrops thanks to the Park's intensive survey campaigns (Mário Reis, personal comment). 


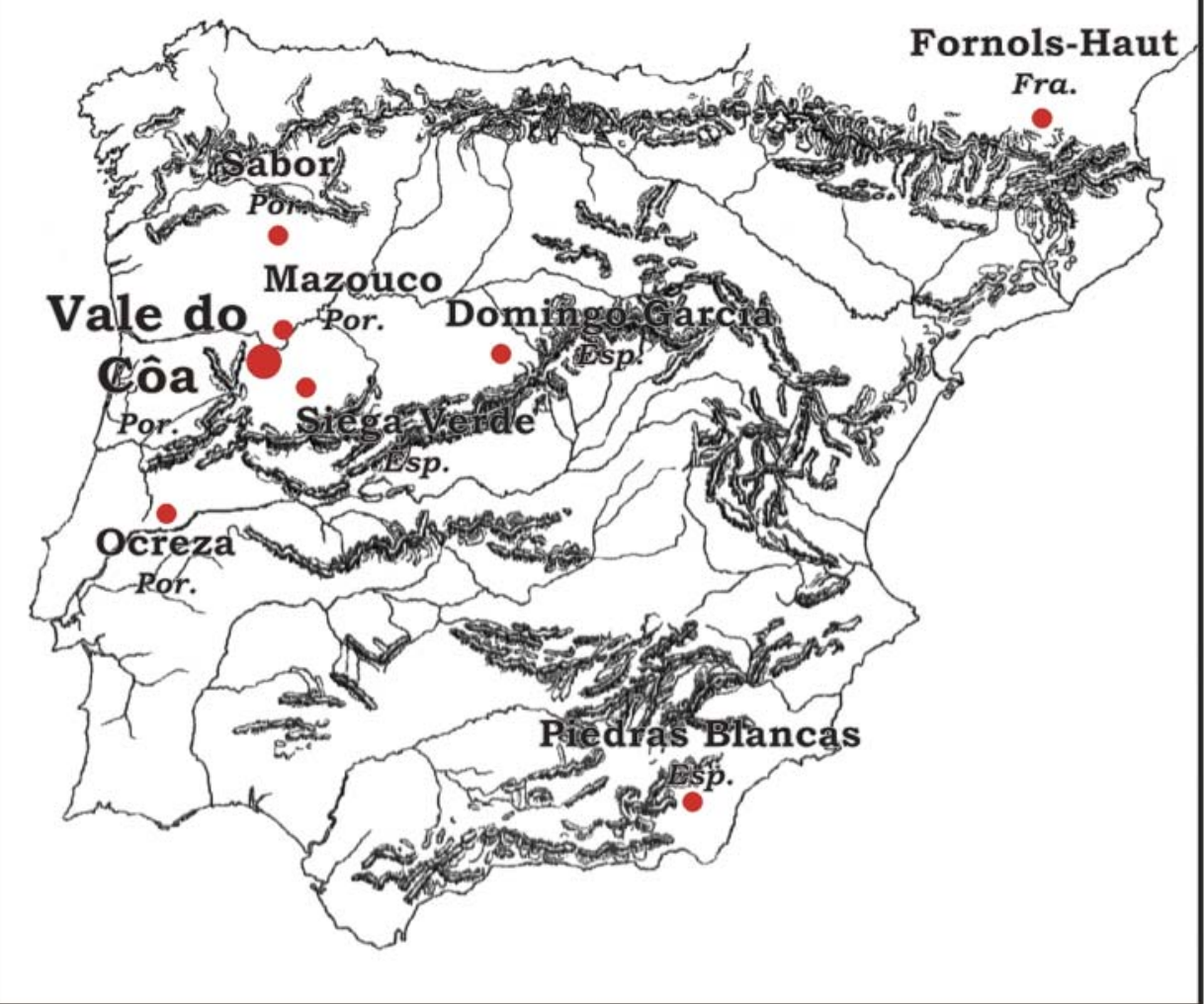

FIGURE 1 Location of the Côa Valley and other open-air rock art sites in the Iberian Peninsula

Map by Luís Luís.

Modern economic models of land exploitation, however, have more destructive characteristics, for instance a schist quarry located above the Canada do Inferno rock art site (Figure 3). Normally schist extraction involves the use of explosives which can affect the stability of the engraved outcrops in the area. Another issue is the existing dam system in the Douro river basin which has in recent years made the water level rise in the final section of the Côa, causing great disturbance to the natural flow of the river. The Pocinho dam even submerged some engraved surfaces along the shores of both the Douro and the Côa. The dams, coupled with winters of heavy rain, have also led to some engraved outcrops being temporarily submerged by the rising river level (Figure Io), and this sometimes sudden variation of the water level has a negative impact on the preservation of these outcrops (see below).

Sheep farming can also influence the preservation of the rock art. In summer some shepherds set fire to bush areas, convinced that the vegetation will grow stronger and greener the following year, giving more pasture to the animals. While in the short term this is true, in the medium and long term this practice results in the progressive 


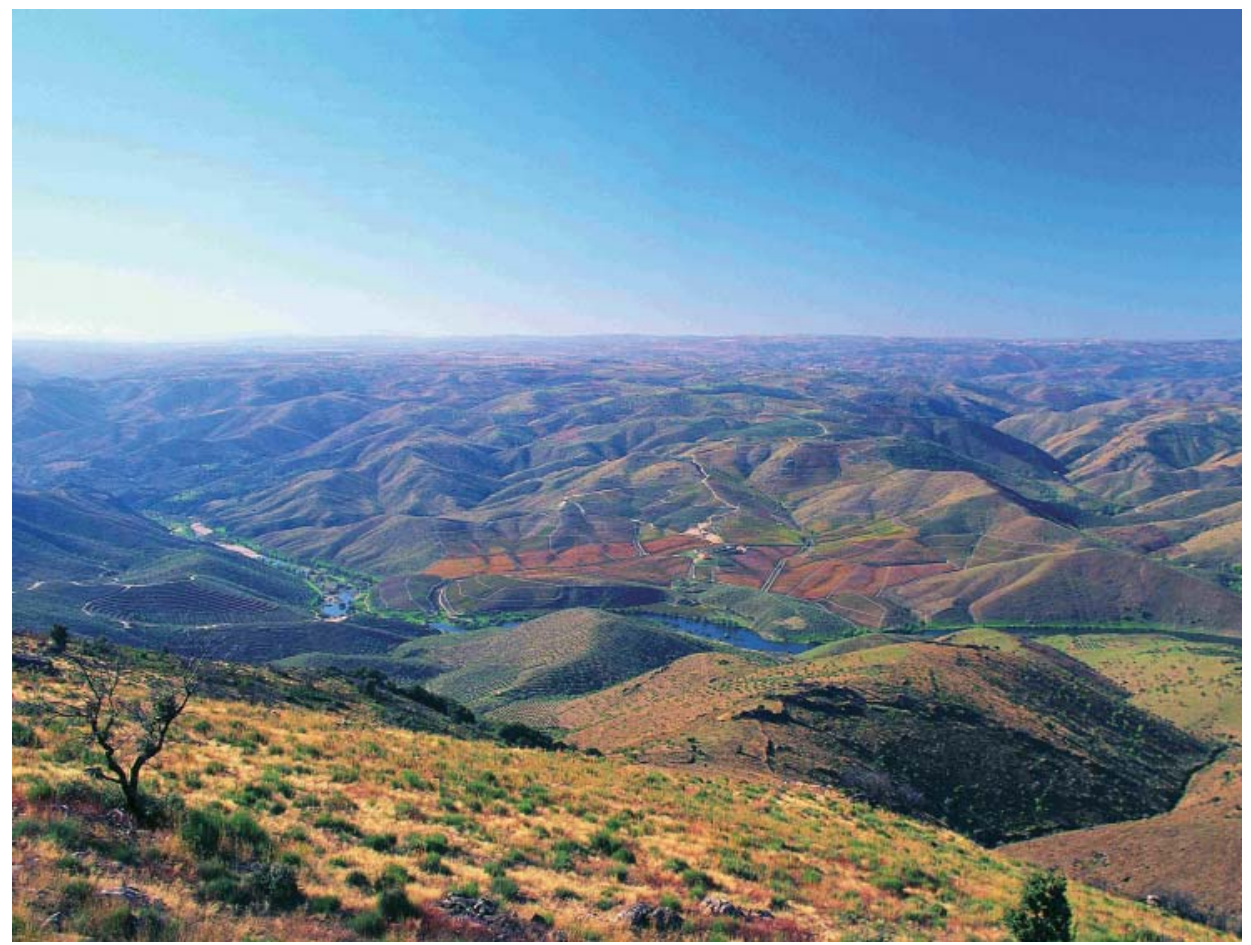

FIGURE 2 The Côa Valley, with the Ervamoira vineyard in the background. Photograph by António Martinho Baptista/CNART.

impoverishment and erosion of soils (Ana Berliner, personal comment). These fires could also have a devastating effect on the engraved panels: the schist in the area is remarkably resistant (Ribeiro 200I), but if heat is inflicted directly upon the engraved surfaces it might hasten weathering dynamics, blacken panels, or even erode engraved motifs (for an account of the damage bushfires can inflict on rock art sites, see Kelly and McCarthy 200I; Manning 2003). Thanks to the constant vigilance of the Park staff, the nature of the combustible material (mostly bush) and good communication with the local fire brigades, to date no fire has directly affected any of the rock art.

Foz Côa is in the port wine production district and a high percentage of agricultural land is used as vineyards. The characteristics of this imply huge soil movements, often near watercourses, in order to create the terraces necessary to plant the vineyards. The construction of these can affect the stability (and even the existence) of the engraved outcrops, especially when this is done illegally. The PAVC staff observe these scarifying procedures, normally at the request of the owners or the municipality, but also on their own initiative: it is of paramount importance to keep a tight watch over areas near rock art sites to prevent unlicensed scarifying procedures from destroying rock art. 


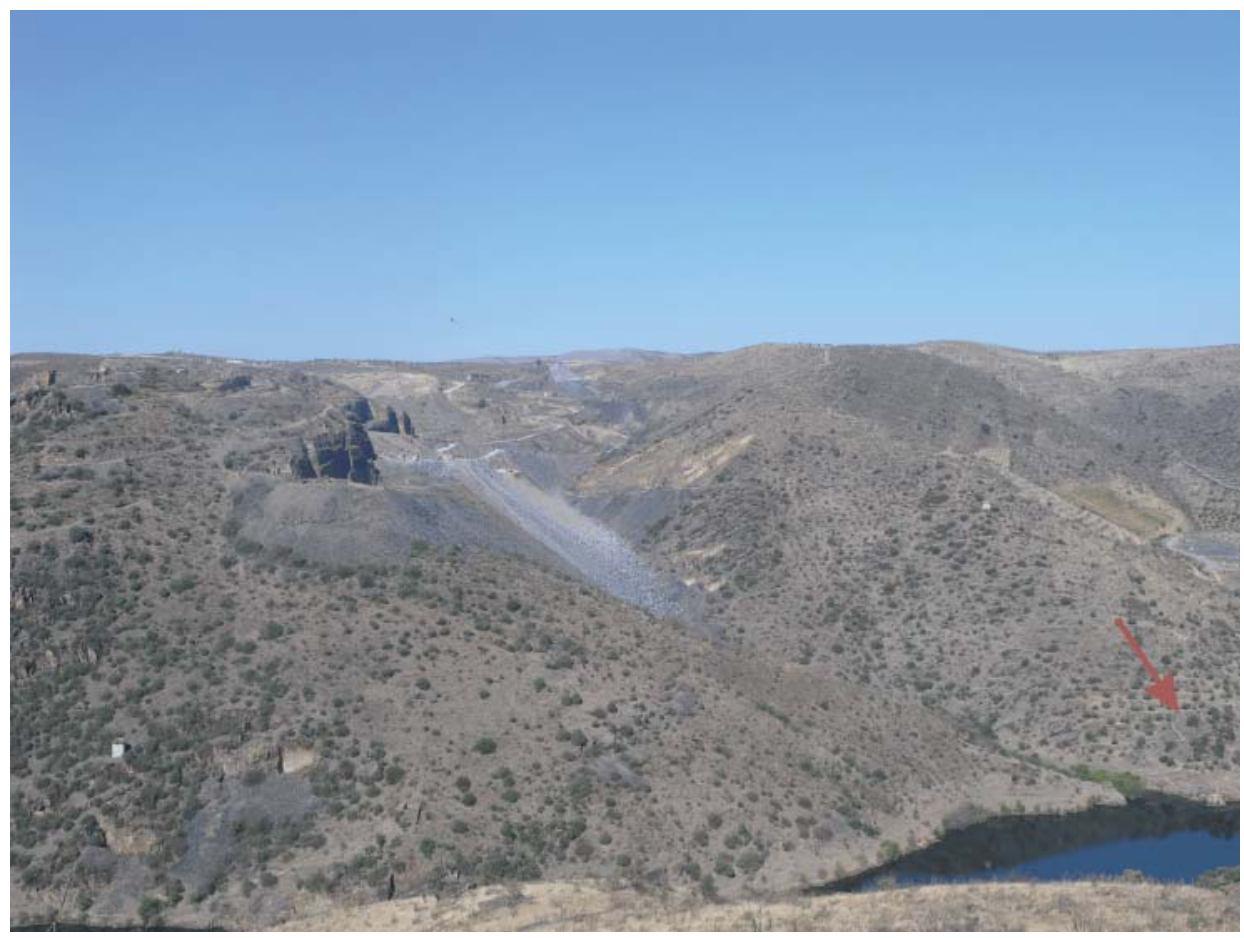

FIGURE 3 Poio Quarries. The arrow indicates the canada, a steep narrow valley, at the bottom of which is the Canada do Inferno rock art site.

\section{Geology and seismicity}

A large portion of the PAVC territory is composed of metamorphic formations (most of them meta-greywaches and schists) belonging to what is known as the Complexo Xisto-Grauváquico (CXG - Schist-Greywachian Complex). The deposition of this geological complex, which occupies a large portion of Portugal, began in pre-Cambrian times, some 540 million years ago. As a result of the variety of original sedimentary environments, this is lithologically very diverse (Ribeiro 200I). The metamorphic bedrock created 'ideal' surfaces for rock art, as the gradual river down-cutting process caused the emergence of smooth vertical panels (Figure 4 ). The exposure and fracturing of these surfaces are consequences of river down-cutting and tectonic processes upon previously deposited metamorphic rocks (Aubry et al. 2002a; García Diez and Aubry 2002).

The area occupied by metamorphic outcrops is divided into three distinct formations, each with different characteristics: Rio Pinhão, Pinhão and Desejosa (Ribeiro 200I). The majority of the identified rock art sites are located on the Desejosa formation. No rock art sites have been identified yet on the Rio Pinhão formation and only two rock art sites, Penascosa and Quinta da Barca, have been identified on the Pinhão formation. In addition, two sites, Faia and Ribeirinha, have been located in hercynian sintectonic granites, which date from more recent times (around 320 million years). The Ribeirinha site is situated in the granite formation known as Granito de 


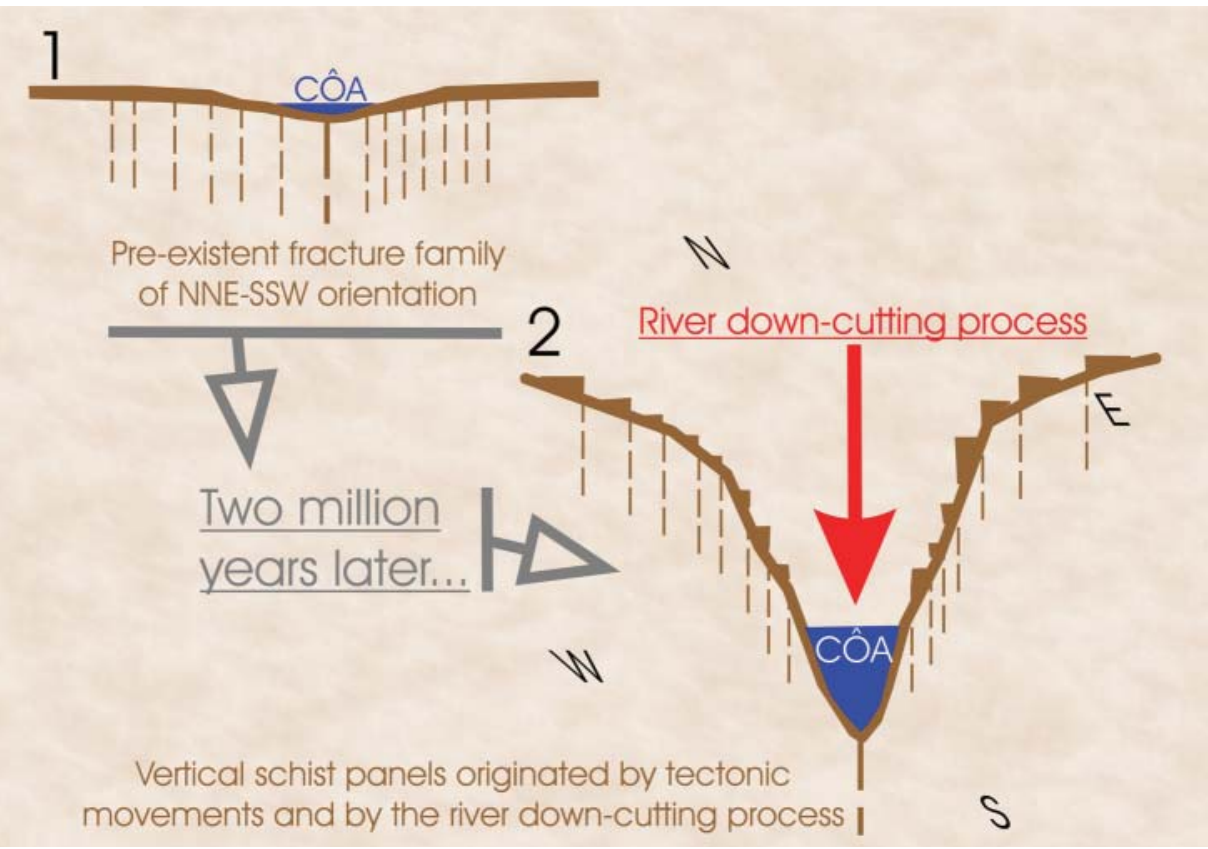

FIGURE 4 Schematic illustration of the Côa River down-cutting process, which, in the last two million years, has exposed the vertical schist panels that were later engraved.

Mêda-Escalhão, while the Faia rock art site is located in an area formed by outcrops of Mêda-Escalhão granite intercalated by outcrops of the formation known as Granito de Massueime-Galegos.

Among the tectonic faults in the region the most significant is the VilariçaLongroiva fault. This feature 'is a complex accident, with fractures of kilometric band width ... [and] judging by the deformation of the relatively recent sediments and contemporary seismic activity records' (Ribeiro 200I, 6, author's translation) its activity continues up to the present day. The existence of this active fault is potentially dangerous (and not at all controllable) for the preservation of rock art.

\section{Schist weathering mechanisms and geological dynamics}

The schist, on which most of the rock art motifs were inscribed, has a distinct tendency to auto-fracture, which, crucially, determines the approach to in situ conservation work. As it is impossible to completely stabilize schist outcrops there is a precarious equilibrium: these are not immutable monoliths. It is essential, therefore, to monitor the development of weathering patterns, the stability of the outcrops, and to collect information on the urgency of conservation work. The necessity of carrying out actions needs to be fully demonstrated as there is virtually no margin for error: we must resist the temptation to implement ill-considered actions, as they could hasten the natural dynamics and damage the rock art. We consider it a priority to carry out minor interventions, as reversible as possible, so as to minimize the consequences of these geological, biological or mechanical dynamics. The objective is 
not to try to arrest the normal evolution of these dynamics, but to reduce or neutralize their negative effects, if technically, mechanically or ethically possible.

We must also consider that any conservation action always implies a change in the physical appearance of the outcrops and panels. This can raise important aesthetic or even ethical issues, even if it is possible to recreate the visual and tactile characteristics of the panels and outcrops, trying to disguise the alterations made.

\section{Different scales, different problems}

It is helpful to distinguish between the different scales of impact diverse dynamics have, either directly or indirectly, on the preservation of the engraved outcrops (Figure 5). This is an artificial division - in the natural environment these problems do not act in the rigid way this segmentation suggests - but we believe that a multidisciplinary description of the dynamics at work is useful in order to define the issues that the Conservation Programme must address.

\section{The macro scale}

At the macro scale we can observe all of the conditions at work in the surrounding area, which are mainly dictated by the topographic position of the carved outcrops. Given the natural propensity of schist outcrops to self-splinter, the tendency of the slopes where the outcrops are located is to dismantle: especially as the outcrops are often situated at the base, or halfway up, relatively steep hillsides (Figures 6 and 7). The material that falls from these hillsides exerts critical pressure on the outcrops: for example toppling, a type of horizontal fracture, which results in the progressively echeloned advance of the upper broken slabs, forming a kind of inverted staircase (Rodrigues I999). It is easy to imagine the enormous pressures that the outcrops can be subjected to, and the origin of most of the mechanisms that affect the stability of the outcrops at the micro and medium scales.

The topographic position of the outcrops also contributes to damage, and leads to other geological and structural pathologies caused by the flow of rainwater. However, current rainfall figures for the region are low (Aubry et al. 2002a): possibly returning to conditions prevalent in the Upper Palaeolithic, when precipitation was also very moderate (Aubry I998). This has reduced the effects of rainwater, which may account for the survival of the surfaces and their engravings. Unfortunately, the same cannot be said of any painting that might have accompanied the engraved motifs (Baptista I999): painted motifs, together with engravings, only survive today in the granite shelters of Faia.

\section{The medium scale}

At the medium scale we consider all the biological dynamics active in the surrounding area and directly in the massifs. These include flora (trees, bushes, smaller plants) and fauna (rodents and birds), all possible factors in the disintegration of the outcrops and panels. Also at this scale, the precise weathering processes of each outcrop open or closed fractures, diaclasites, disconnected blocks, toppling, etc. (Rodrigues 1999) - can be seen in a much more tangible fashion. 


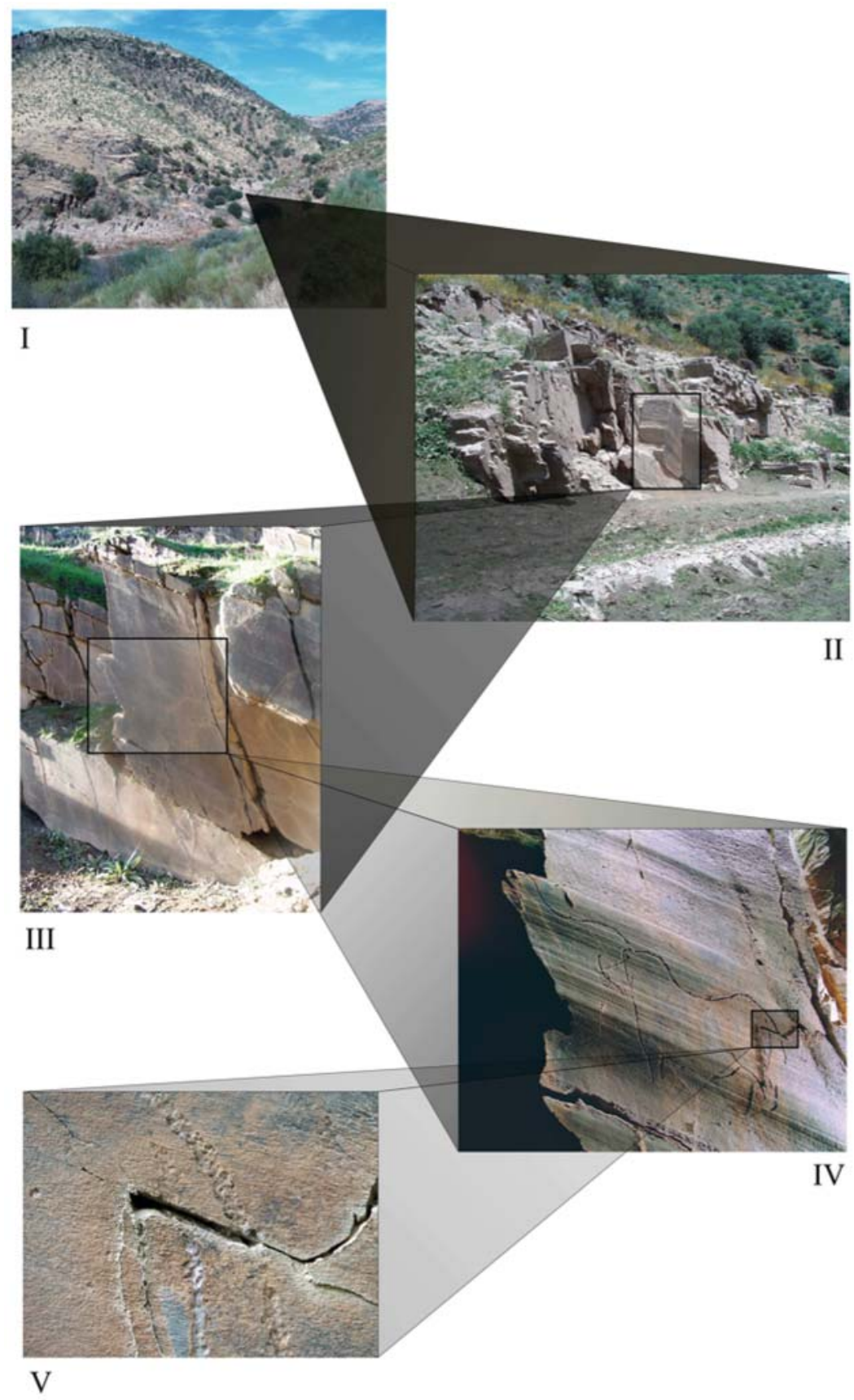

FIGURE 5 Different scales at which weathering dynamics affect an engraved surface, at Ribeira de Piscos Rock 1. Macro scale (I); Medium scale (II, III and IV) - several weathering dynamics can be seen at these scales, including disconnected blocks, toppling, fractures, vegetation, etc; Micro scale (V) - weathering dynamics include micro fractures and exfoliation (near the hind leg of one of the horses).

Photograph IV by António Martinho Baptista/CNART; rest by the author. 


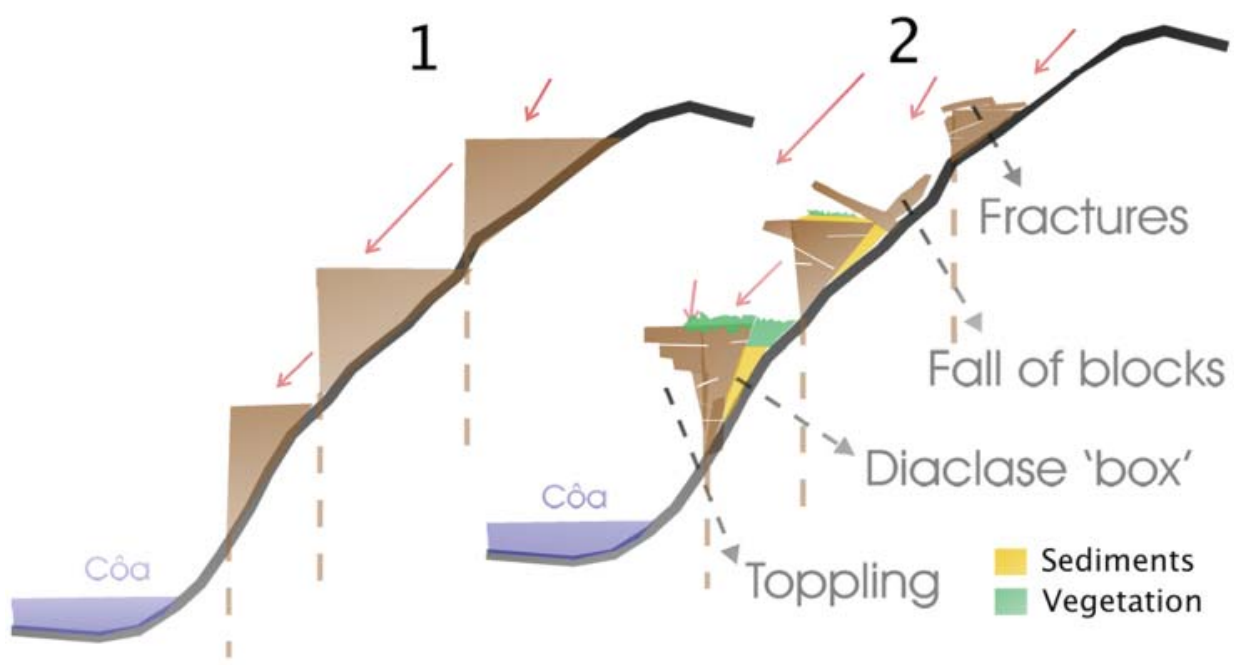

FIGURE 6 Schematic illustration of how gravitational pressures, worsened by seismic activity and rock retraction and expansion cycles (caused by climatic changes), result in the instability of the slopes.

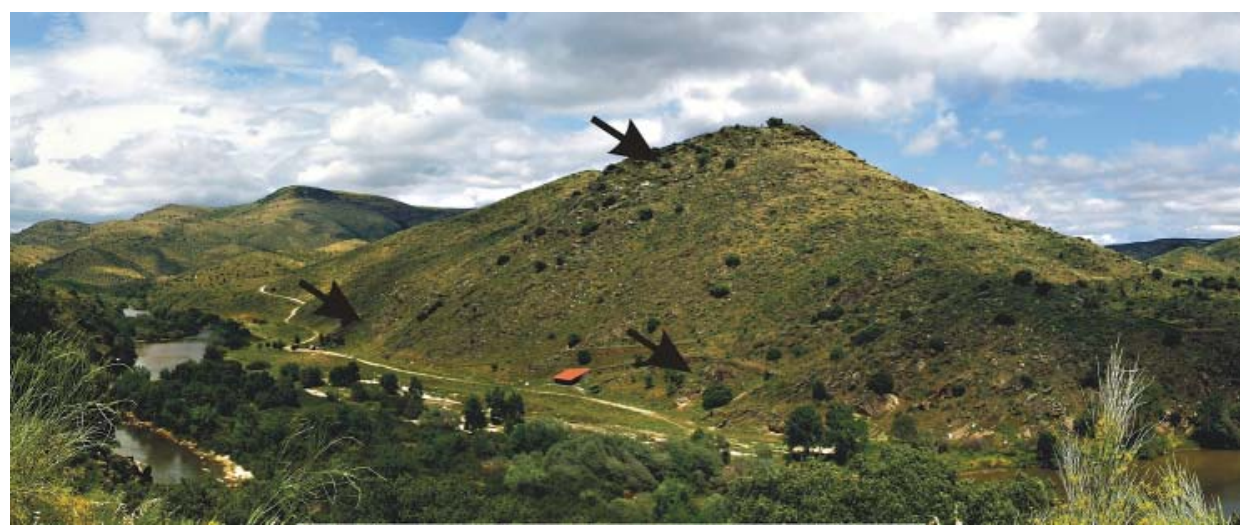

FIGURE 7 Penascosa rock art site. The arrows indicate the areas where the engraved outcrops are located.

\section{The micro scale}

At this scale we consider biological dynamics (biodegradation: Romão I999) that act directly on the panels: lichen colonization, growth of small plants or fungus, or the presence of insects. In general, the effects of these factors can be minimized (if necessary by cleaning - see below).

Geological factors, such as exfoliation, alveolization, scaling, or the development of fissures or microfissures (Rodrigues 1999), often resulting from factors that work on other broader scales, affect the condition of each of the surfaces or engraved motifs. 
At this level, we also have to take into account the siliceous skin that covers the engraved panels (Watchman I995; Zilhão I995; Aubry et al. 200I; Aubry et al. 2002b). This layer is the origin of the patina on the engraved motifs (Aubry et al. 2002b). As such, it has contributed, in differing degrees in each case, to the conservation of the surfaces and the engraved motifs (Aubry et al. 200I). However, this layer is subjected to complex and little-understood deposition/erosion/redeposition processes (Rosenfeld I985; Zilhão I995). Pope (2000) has suggested that the sulci of the engraved motifs may be harder, softer, or the same as the host panels, depending upon the redeposition processes, and that this will vary from site to site, and also within areas of the same panel. In some panels the coating has already completely changed and provides little or no protection to the engravings (Aubry et al. 2002b), and the winter floods of the Côa have caused significant erosion to this protective layer (Aubry et al. 2002b).

\section{Conservation of paintings}

All the painted motifs found so far in the Côa Valley, dated to the Upper Palaeolithic, Neolithic and Iron Age, are located at Faia, Vale Videiro, Vale de Figueira, Ribeirinha and Ribeira de Piscos (Baptista 1999). They have been found in natural shelters, which act as protective shields. It has been suggested that the lessprotected surfaces, where engraved motifs survive, could originally have been painted: either independently or complementing the engraved images (Baptista I999). In general, the preservation of the paintings is dependent on the same pathologies that affect the stability of the other panels.

However, the preservation of paintings poses some specific issues, including percolation caused by precipitation; accidental or deliberate actions by people or animals (ranging from rubbing to total destruction); chemical or physical alterations in the rock caused by environmental changes; and biological colonization (bacteria, fungi, bryophytes, lichens, insects, or plants). Because of the specific demands of painted rock art conservation, the Conservation Programme includes monitoring of the particular pathologies affecting these motifs.

\section{Implications for the conservation programme}

Actions taken to avoid the disintegration of the outcrops and panels, or the effects of inexorable schistosity, will not protect the rock indefinitely. If successful it will only lessen the effects: if unsuccessful - due to deficient analysis or to a lack of data - it could seriously aggravate them. We stress that there is little or no margin for error. Devlet and Devlet (2002), working on south Siberian rock art motifs, also engraved on schistous rocks, describe measures to stop deterioration of the surface (crack filling, impregnation of the surface): these produced irreversible impacts and were complementary factors in deterioration. Today, crack filling, reattachment, massif consolidation, or the impregnation of rock surfaces, are approached with great caution, especially given the scale of unintentional damage which resulted from past interventions (Rosenfeld I985; Andersson 1986; Finn and Hall I996; Walderhaug and Walderhaug I998). Against a background where conservation 
actions are of a complex and delicate nature, there is often little information on the long-term nature of new materials, which are often being used within largely uncontrollable environments (Price I996).

The different dynamics that influence the stability and endurance of the engraved outcrops do not work in isolation and their total effects must be regarded as interdependent, altering each outcrop in a different way. The approach must therefore be holistic, trying to identify the entirety of the dynamics at work, the way in which they affect the stability of each outcrop, and the possible conservation actions to be taken. In trying to understand all the dynamics at work, we follow a caseby-case approach, attempting firstly to understand how these dynamics act at each outcrop, so that afterwards we can decide on the methodology and materials best suited for each situation.

Researchers at the Spanish site of Domingo Garcia - where there are numerous Upper Palaeolithic open-air engravings on schist - followed this methodology. The first stage was to study the geomorphology of the region and the geological factors that influenced the conservation of the schist surfaces (Jordá Pardo I999; Martín Escorza 1999). We should emphasize here the vast number of rock art surfaces, engraved and painted, in the Côa Valley: more than six hundred different engraved surfaces along the banks of both the Côa and the Douro (Figure 8). These surfaces are often located in remote and relatively inaccessible areas, which pose logistical problems for the implementation of conservation work.

\section{The Côa Valley Rock Art Conservation Programme}

The Conservation Programme was written for the Proposta de criação do Parque Arqueológico do Vale do Côa (Proposal of creation of the Côa Valley Archaeological Park) (Cabral and Coelho 2002). The document was prepared by the PAVC in partnership with the Institute of Environment and Development (IDAD), University of Aveiro, and corresponds to the procedures defined by Portugal's cultural heritage law (Law I07/200I, 8 September 200I, no. 7, art. 75).

\section{Actions in the programme}

\section{Documentation}

Comprehensive recording is fundamental for understanding the evolution of the geological, biological and mechanical dynamics that directly or indirectly affect the state of conservation of the rock art outcrops and panels. This requires the use of numerous methods, such as photography, drawing, topography, and $3-\mathrm{D}$ techniques. We have been developing, together with international students and archaeologists (particularly Jennifer Huang), documentation methods specific to conservation assessment (Figure 9). These cover lithic weathering, and micro and medium biological issues, for each engraved panel or outcrop. They are also used for type-rocks: these are surfaces without engravings, but with weathering dynamics analogous to the engraved ones (see below). Such documentation also acts as a basis for recording future conservation work on the panels. Digital high-resolution photography of 


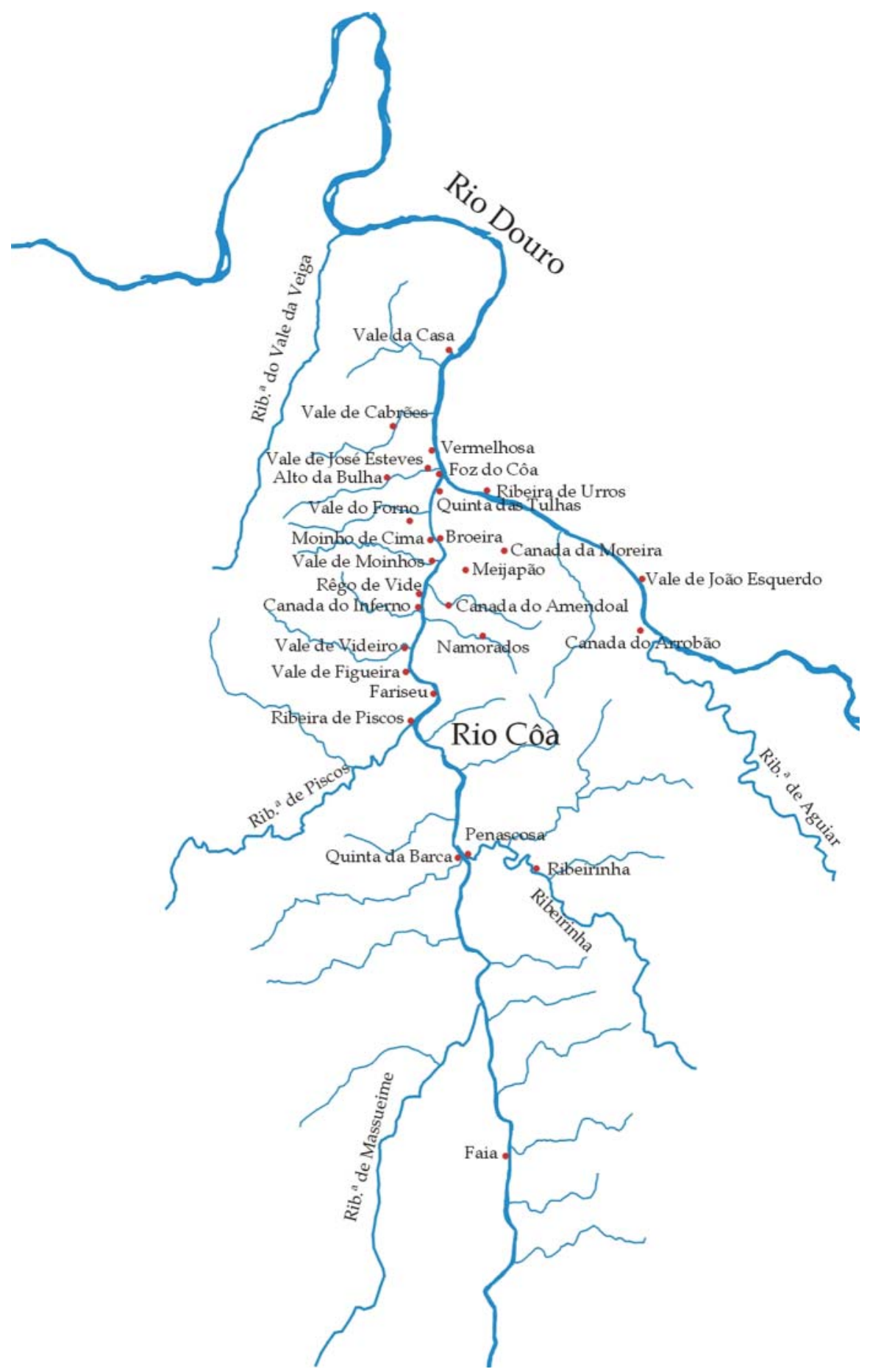

FIGURE 8 Distribution of the rock art sites along both margins of the final $17 \mathrm{~km}$ of the Côa and part of the Douro.

Map by Luís Luís. 


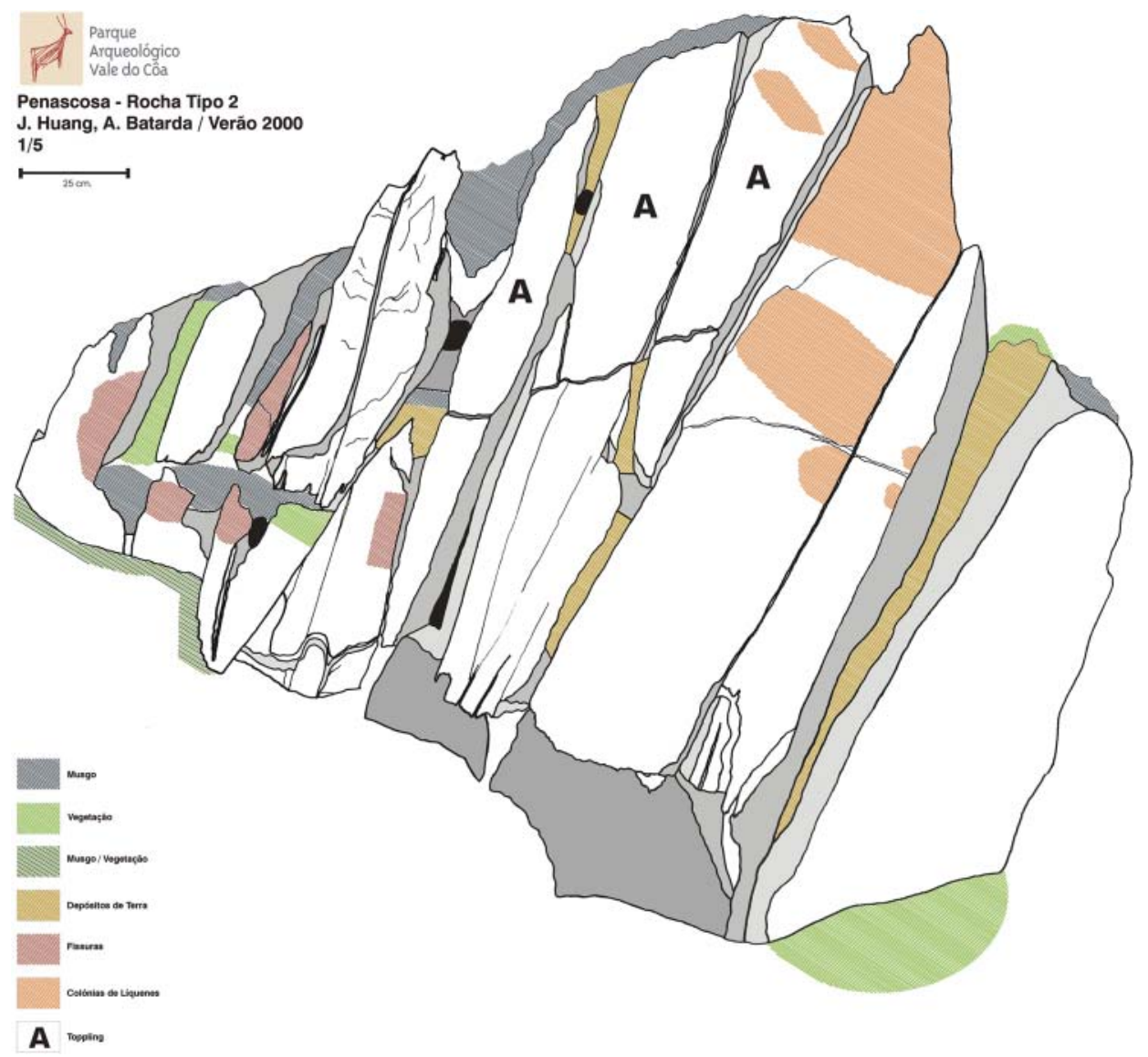

FIGURE 9 Representation of weathering dynamics on type-rock no. 2.

particular areas of the panels and outcrops is also being employed. All the information is held in a database specifically created for the programme (see below).

\section{Monitoring}

The documentation allows for regular systematic monitoring of the rock art panels and their outcrops. Observation of changes in the state of the outcrops can be easily included, and comparisons regularly made. High-resolution photographs are also used to trace changes in the fissures and fractures of the panels. Points of reference are located digitally in the photographs so that later in situ measurements can be taken. Comparison between the data gathered by this periodic documentation provides a way of assessing the development of these pathologies. This method has been adapted to trace changes in other dynamics, such as the colonization by lichen or erosion of the siliceous layer. To measure the distance between reference points we use a quantum digital pachymeter with a resolution of between $0.0 \mathrm{Im}$ and $0.03 \mathrm{~mm}$. All this data is added to the conservation database. 
The implementation of a monitoring system for topography, expanding the measurement of the changes in the panel fractures to a broader scale, is still in the design phase. This expansion is intended to ensure that any movements in engraved outcrops, in the medium and macro scale, can be observed.

\section{Evaluation}

The information collected during monitoring is analysed, either by the Park, by experts of the International Commission on Conservation, or by other specialists. Evaluation is fundamental in establishing the urgency and practicability of conservation work. The result of this evaluation is also included in the conservation database.

\section{Stereo-photogrammetric documentation}

Stereo-photogrammetric documentation can be useful as a method to document and monitor schist pathologies. It also provides data to create exact replicas of fragile panels, although this is seen as the last resort to assure the physical endurance. To produce three-dimensional models, a protocol was established with the Instituto Nacional de Engenharia e Tecnologia Industrial (the National Institute of Industrial Technology and Engineering (INETI)) and the Centro Nacional de Arte Rupestre (National Centre for Rock $\operatorname{Art}^{\mathrm{I}}$ (CNART)) (INETI 200I).

\section{Conservation database}

The database, developed in Microsoft Access, is updated with information collected in the documentation and monitoring processes. In addition, any cleaning or conservation actions are documented in the database.

\section{Prior testing}

Experimentation is crucial, since there is almost a complete ignorance of the reaction and behaviour of granite and schist in in situ outcrops when subjected to conservation treatments: the Côa Valley is the 'live' laboratory where this subject will be researched.

In order to evaluate the reaction of the schist outcrops to consolidation, stabilization and cleaning materials - techniques that may be useful in minimizing the outcome of weathering dynamics on the carved outcrops - it is very important to begin by experimenting on type-rocks. The outcome of this experimentation, which is also monitored and recorded in the conservation database, is fundament to assess their potential value in future conservation work. As the analysis published by Oddy and Carroll (I999) demonstrates, no conservation technique nor material is Ioo per cent reversible and thus carrying out tests is even more indispensable, as any future conservation treatment will be hard, if not impossible, to undo.

\section{On-going studies}

A variety of studies are needed to understand fully all the issues that influence the conservation of the Côa Valley rock art. Besides further knowledge of all the active phenomena, specific analyses enable us to draw up conservation work proposals 
adapted to each precise case. These studies also permit accurate budgeting and the definition of the logistics required to implement conservation work.

Three different Portuguese stone conservation companies were asked to carry out these experimental studies on un-engraved outcrops. The International Commission on Conservation (see below), represented by the geologist Delgado Rodrigues, gives support to these studies. The aim of the studies was to define the methodology and materials to be used in the future and to examine the natural condition of the outcrops.

The studies demanded a multidisciplinary approach. A number of studies have been or are being commissioned, on climatic, morphological, petrographic, hydrological, geological and biological issues: the principal projects are outlined below.

\section{(i) Geology: stability of the outcrops}

Delgado Rodrigues, researcher of the Laboratório Nacional de Engenharia Civil (the National Laboratory of Civil Engineering (LNEC)), produced a valuable report that identifies the pathologies and mechanical problems affecting the stability of the schist outcrops and the survival of their engraved panels (Rodrigues I999). He also made recommendations for developing a working strategy aimed at minimizing weathering mechanisms, and suggestions for the implementation of a methodology for documenting weathering dynamics, which we have tried to implement in the above procedures.

\section{(ii) Colonization by lichen}

Paula Romão, a biologist and expert in lichens, has produced a report on the lichen colonization of schist rocks in the PAVC (Romão 1999). The report provides essential information on the general characteristics of these organisms, as well as identifying the morphology of the different saxatile lichen species found in the Park. Among these are Aspicilia spp. and Caloplaca irrubescensis (classified by thallus morphology as encrusting); Parmelia conspersa and Parmelia saxatilis (classified as foliaceous) and Collema sp. vv. (classified as gelatinous) (Romão I999, 8). The report also describes the action of the natural mechanisms of these lichens on the lithic substrate (Romão I999, I2).

\section{(iii) RockCare Project}

The PAVC was a partner in the EU-funded RockCare Project, managed by the Swedish Heritage Board, with the Italian Centro Camuno de Studi Preistorici and the Finnish Heritage Board. This project included several studies and recommendations that form part of the conservation programme. Among these was the $3 \mathrm{D}$ scanning of engraved rocks using the Moiré technique (which obtains three-dimensional digital images of surfaces, similar to the ones obtained by INETI), and the study by a Finnish expert of lichen colonization of the engraved surfaces in the Park (Vänskä 200I).

\section{(iv) The Stanley-Price Report}

In 1996 Nicholas Stanley-Price, a cultural heritage management consultant and former president of the International Centre for the Study of the Preservation and 
Restoration of Cultural Property (ICCROM), undertook an evaluation report to assess the protection measures and the public presentation of Côa rock art, to recommend the composition and role of the proposed International Commission on Conservation of the Côa Valley Archaeological Park, and to advise on further training for PAVC staff (Stanley-Price I996).

\section{(v) International Commission on Conservation Report}

A Commission was therefore appointed, comprising of Nicholas Stanley-Price, Delgado Rodrigues, Maria Isabel Prudêncio, Thomas Wyrwoll, Sharon Sullivan, and Antoinette Padgett. In 1997 this Commission produced a report (Stanley-Price et al. I997) for the PAVC Conservation Programme, which set out the philosophy and practical approaches of the Conservation Programme.

\section{(vi) Geological map of the PAVC}

A uniform geological map of the PAVC, together with explanatory notes, is an indispensable tool for systemizing knowledge of local geology, geomorphology, and seismicity, and thus for understanding the geological dynamics that affect the stability of rock art. Since the Park territory was divided between four different geological maps, and even those had some flaws and gaps, it was one of the Park's priorities to produce a unified document. After establishing a protocol with the Portuguese Institute of Geology and Mines (IGM), a map was produced by the IGM geologist Maria Luísa Ribeiro (200I).

\section{(vii) Alteration processes and preservation of engraved surfaces}

Since 1999 a team led by the PAVC archaeologist Thierry Aubry and composed of the Swiss archaeologists André Calame and François-Xavier Chauviere, the French ethnologist Isabelle Dechanez, and the Park's assistant archaeologist Jorge Sampaio, has been investigating the alteration and preservation processes of the siliceous layer that protects the engraved panels. The research diagnosed the condition of the layer in some panels and gathered samples to create a collection of Côa Valley metagreywaches, fundamental to the petrographic characterization of the schists and of the protective layer. Analyses were conducted by the Geological Institute of Neuchâtel University. An examination of the deposition and redeposition processes of the siliceous film was also carried out (Aubry et al. 200I; 2002b).

\section{(viii) The Poio quarries}

The Poio quarries, located above the Canada do Inferno rock art site (Figure 3), threaten the condition of the engraved surfaces: waste dumping and recurrent explosions are real and dramatic hazards for the rock art. The Park commissioned a consortium of IGM (Instituto Geológico e Mineiro) and VISA (Consultores de Geologia Aplicada e Engenharia do Ambiente) - applied geology and environmental engineering consultants - to produce a study (IGM and VISA 2000) about how to mitigate the threat to the carvings; harmonize the present, often anarchic, operational structure; find a way to minimize the environmental impact; and restore the area's damaged landscape. The project also included wide-ranging public 
consultation. Unfortunately, after the conclusion of this study, the quarry companies refused to accept its recommendations, and these have not been implemented.

\section{(ix) Seismicity}

From October 2003 to October 2005 a seismic activity monitoring system operated at the Canada do Inferno site. This seismic station resulted from a protocol established with the University of Lisbon Geophysical Centre. Its aims were to measure natural or man-made seismic activity in the area of the PAVC. It is important to monitor such activity in the Canada do Inferno area since several schist extraction companies are working close by, as discussed above (Figure 3). The objective was to measure the intensity of the explosions, and of local natural seismicity, so as to correlate changes in the condition of the engraved outcrops with this activity. The systematic and continuous collection of data on seismicity enables comparison with measurements of changes in the stability of the rock art outcrops (see section 2 above), particularly changes in diaclasites, fissures, and the progression of topling blocks.

\section{(x) Climate}

Understanding climate, and the annual, monthly and even daily variability of the weather, is instrumental in the conservation of the Côa Valley rock art. The Portuguese Water Institute (INAG) provides data that enables us to calculate annual rainfalls the precipitation rate at a certain height above sea level (for instance at the bottom of the valley) (see Aubry et al. 2002a, 62) and to understand the Côa flow regime.

However, this data is insufficient to characterize the local and regional climate completely. Information about temperature (annual, monthly and daily variations between and within the different rock art sites, or on one or several engraved surfaces) is also vital. Therefore at the beginning of 2004 a WatchDog 700 weather station, which monitors temperature, precipitation, and relative humidity, was installed in the Penascosa rock art site. It also measures temperature inside two different non-engraved outcrops, so as to give an idea of the temperatures that schist outcrops can reach at their core.

\section{Cleaning, consolidation of surrounding areas, and vegetation control}

Cleaning and consolidating the zones surrounding the engraved outcrops and the area of the rock art sites is necessary to restrict the uncontrolled growth of vegetation and to prevent occasional landslides from putting excessive pressure on the massifs. Even though local rainfall is light, efforts are, nevertheless, made to prevent rainwater from percolating through the schist outcrops: this is done by the creation of drainage systems, as unobtrusive as possible, for each outcrop. Proper management of the growth and distribution of vegetation can also be used to control this problem. The erection of protective structures (shelters or roofs) is a debatable option, since they may have a negative aesthetic impact, and may also lead to unpredictable microclimates, harmful to the stability of the outcrops.

\section{(i) Occasional cleaning of panels}

Certain panels are cleaned occasionally. At the rock art sites open to the public Canada do Inferno, Penascosa and Ribeira de Piscos, a small number of panels are 
covered by sediments deposited by the Côa when the river overflows its banks and floods the sites in rainy winters (Figure Io). After the river returns to its normal level it is necessary to remove the rubbish left on the sites and clean off the muddy sediments obscuring the motifs that had been submerged. We have developed a non-aggressive cleaning method that uses water from the Côa and a sponge made of flexible polyurethane foam (similar to bath sponges). After dampening the sponge in a bucket of water, we gently press the area of the panel without scrubbing, so that the sponge absorbs the sediments deposited by the river, which are then removed from the sponge by washing. The operation is repeated as many times as necessary to clean the panel, whilst the water in the bucket is replaced regularly. Even though this occasional cleaning may expose the panels to a certain stress, we have not noticed any negative changes in the condition of the small number of panels involved since the winter of $2000 / 200 I$, when we first used this method.

\section{(ii) Lichen removal}

The removal of lichens from certain panels is a subject that in the past aroused fierce controversy (see Swartz 1997). Before we began working in the PAVC, several rock art surfaces had been cleared of lichen, motivated by the documentation and public preservation of the engraved motifs (the presence of developed lichen colonies on some panels prevented the full recording of the engravings on those surfaces and, at the same time, obscured some of the motifs from view by visitors). This cleaning was done with the utmost care, causing no damage to the treated surfaces (Fernardo Maia Pinto, personal comment; António Martinho Baptista, personal comment), as confirmed by the International Commission on Conservation (Stanley-Price et al. I997).

Although understanding the reasons that led to the removal of lichens, we no longer see this as a priority. Although some still advocate lichen removal (for instance, Booth Childers I994), we believe that lichen colonization has become an

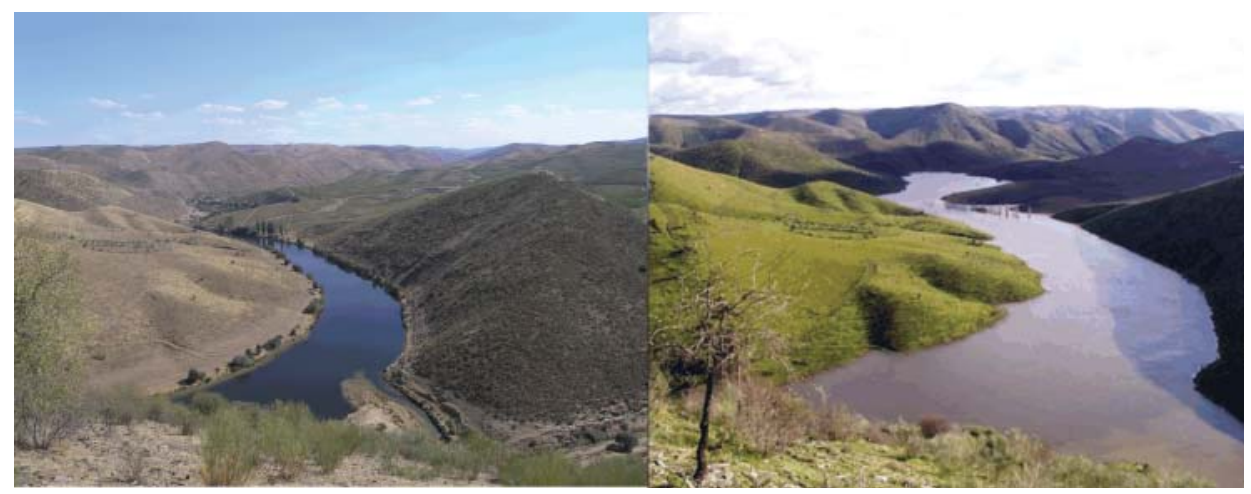

FIGURE 10 Photographs taken above the mouth of Ribeira de Piscos (Creek of the Little Birds), which gave its name to the rock art site. On the left: the normal level of the Côa. On the right: photograph taken on 6 January 2003, showing the highest flood level that year, when the river rose $10 \mathrm{~m}$ above the normal winter level. 
integral part of the engraved panels, thus adding to a whole modified by time, the outcome of alterations caused by the natural life of the landscape. Although lichen colonies may lead to some biodegradation (Romão I999), the removal of lichens may eventually result in damage to the engraved surfaces (Vänskä 200I), which reinforces our conviction. The removal of lichens might be carried out in the future, but only after meticulous analysis of the benefits and harm of such an action in each specific case.

We should also mention the potential use of lichens in the dating technique known as lichenometry (Innes 1985; Stanley-Price et al. I997). This method still has many problems when employed to date rock art and is not yet accepted by the wider scientific community, since weather conditions, which influence lichen growth decisively, vary greatly from location to location. Nevertheless, lichen removal inhibits the future collection of samples. We must therefore balance present-day research with respect for techniques that may produce results in the future. There are still many engraved surfaces where lichen colonies are intact, since lichens were removed from only a few panels (Fernando Maia Pinto, personal comment; António Martinho Baptista, personal comment).

\section{(iii) Graffiti cleaning}

Acts of vandalism on engraved or other surfaces are fortunately very rare. The implementation of a public access system, in which 24-hour surveillance of the three open sites is a fundamental component, has probably played a major role in avoiding such incidents (Fernandes 2003).

Graffiti has been done with sharp objects (keys, rocks, sticks, knives, etc.) on nonengraved surfaces: fortunately there has not yet been any painted graffiti. We usually try to remove the marks, as it has been argued that graffiti attracts graffiti (Jacobs and Gale I994). The scratches can be removed or greatly diminished in visibility just by rinsing with a sponge. Generally, it can be argued that recent graffiti has little historical or aesthetical relevance, since most is rough or naive imitations of Palaeolithic engravings (Figure II), obscene, or just casual doodles.

Regrettably, more serious incidents occur in which a 'fine line' incision was made on top of existing carvings (one from the Palaeolithic and the other from the Neolithic) (Fernandes 2003). Removing it, or trying to diminish its impact, is a delicate operation since the incised motif is superimposed on the existing figures, which were also done in fine line technique. Furthermore, this graffiti motif can also be seen as already a part of that panel: even though it is less significant, both historically and aesthetically, than the primitive figures, and has destroyed the previous 'coherence' of the panel, we believe that this motif has its own meaning. Its significance is broadened if we consider that it was inscribed on top of existing figures, something that demonstrates a certain continuity (conscious or unconscious) of the superimposition tradition one of the key characteristics of the whole Côa Valley site (Baptista I999), common to the Upper Palaeolithic, Neolithic, and Iron Age. For us there is no easy solution to the dilemma: to remove or not to remove. This panel, because of access difficulties, does not form part of the visitors' circuit of the Penascosa rock art site, and consequently it may not attract more graffiti. Nevertheless, preliminary plans are being made for its removal, the first step being recording 


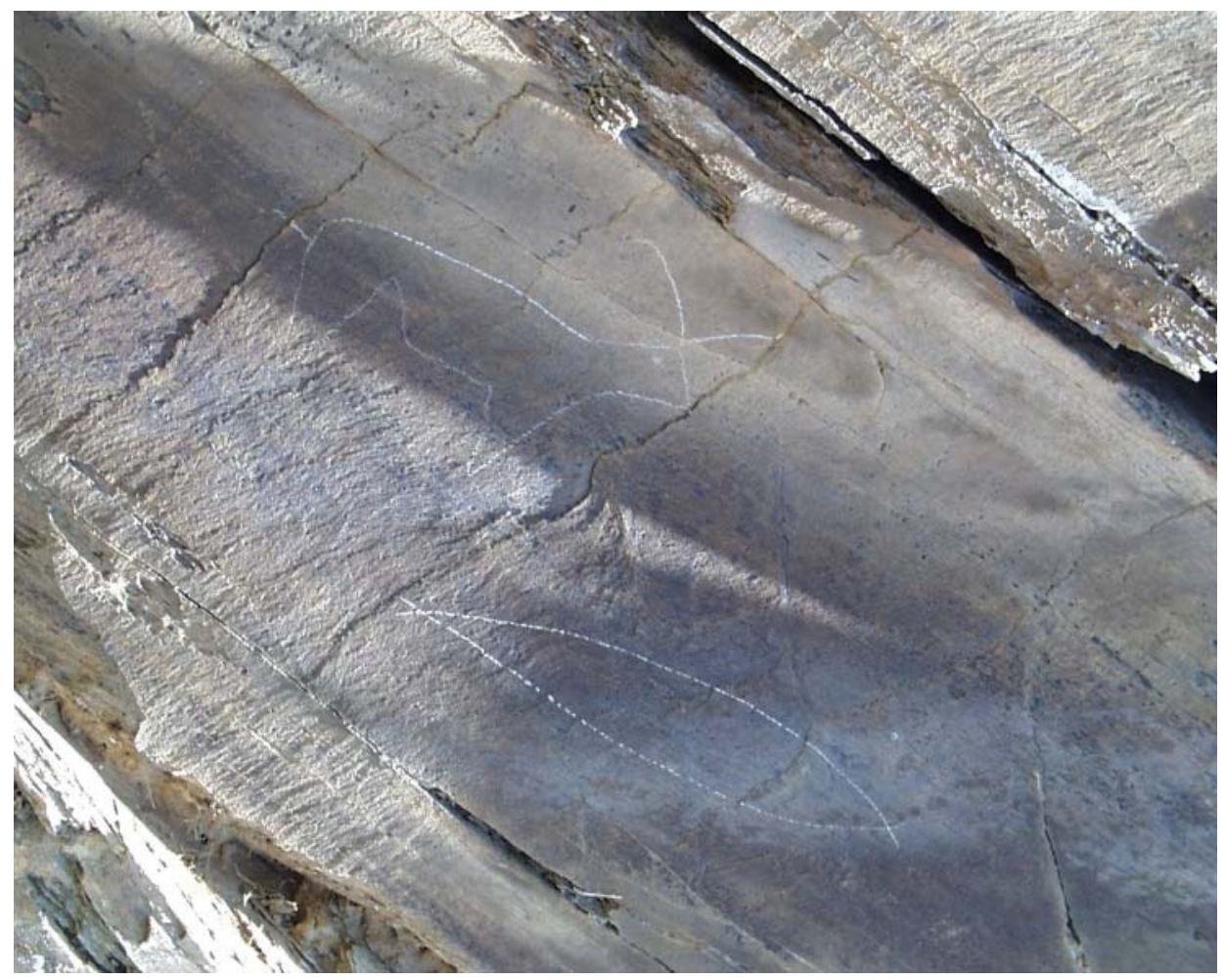

FIGURE 11 Graffiti on a non-engraved surface of the Penascosa rock art site.

and documentation. It will be removed only after the feasibility of the action and its impact upon the original motifs has been thoroughly assessed.

\section{Interconnection}

Interconnection is being developed between the conservation database, other databases in the PAVC, and the Geographic Information System currently being developed in the Park. This interconnection will result in the integrated accessibility of Conservation Programme data, together with all the information recorded in the archaeological sites and rock art databases.

\section{Internships and placements}

In the last few years, as a result of a partnership with US/ICOMOS, the PAVC has welcomed several American interns. Interns contribute to the documenting of conservation work, especially in the cartographic recording of schist pathologies. Besides this partnership, specific research projects or internships connected with conservation work are welcome. There have been many students and professionals - from Japan, Greece, Australia, Italy, the USA, Britain, Guatemala, etc., and from educational institutions such as the Institute of Archaeology, University College London - who have spent time in the PAVC, studying specific conservation issues and helping to enhance the Programme. 


\section{Advanced training}

Advanced training of PAVC team members in the area of conservation is a priority. The objective is to provide the PAVC with the qualified human resources needed to manage and execute the objectives of the Conservation Programme. It was decided, for example, to send the author of this article to do an MA in managing archaeological sites, at the Institute of Archaeology, University College London. Whilst not specifically about rock art sites, the course presented an opportunity to undertake research in the management and conservation of such sites, leading to a final dissertation which examined the importance of public access systems in the preservation of these sites (Fernandes 2003).

We have also conducted several workshops with PAVC guides on the philosophy, objectives, and actions of the Conservation Programme. These workshops are instrumental in raising visitors' awareness of issues around the protection of national heritage in general and of the Côa Valley rock art in particular. Since the guides are the visible face of the PAVC, they are the ideal ambassadors to show the public how they can contribute to the preservation of cultural heritage.

\section{Scheduling}

The collection of data to begin legal protection (scheduling), as required by the Portuguese Heritage Law, is part of the Programme. The process involves gathering ownership data, indispensable to the efficient management and preservation of the rock art sites. In Portuguese Heritage Law scheduling is the main legal tool for the protection of cultural heritage sites.

As soon as new rock art sites are identified, the Park starts collecting data concerning the property, contacts the landowner(s), carries out topographic mapping of the area and gathers all the necessary photographic and/or graphic data. All this documentation is then forwarded to the Portuguese Heritage Institute (IGESPAR), the state body that classifies Portugal's significant cultural heritage sites, buildings or assets, so that the scheduling process can be set in motion.

\section{Educational activity}

Actively involving the local population and the general public in the protection of a heritage that belongs to all must go beyond the role played by guides, important though this is. Wider involvement of the population is achieved by targeted campaigns, information boards, meetings, and open days. In the case of the latter, this involves not only visits to sites, but also to the Park's headquarters, where first-hand contact with the staff and the work fosters mutual understanding.

Moreover, in our view, the PAVC must try to actively connect with the community to explain the importance of Côa rock art and its preservation. Although our personal experience in this area has not always been completely rewarding, we believe that the relationship with the local population must be managed with complete openness, especially regarding the scheduling procedures, so that the community feels that their opinion counts. As a result of our personal experience we have tried to develop an informal style, using accessible language, especially since we experienced some difficulties communicating with older age groups, who can have larger numbers 
of less well-educated individuals. It is also crucial to reach socially influential local personalities (politicians, teachers, priests, etc.), since they often determine the acceptance of heritage preservation concepts by the local population.

Likewise local schools should also be involved in the preservation of cultural heritage. Besides other activities, the RockCare Project enabled a group of Foz Côa high school students and teachers to participate in the World Heritage Youth Forum. To enable the students to present the Côa Valley, they participated in excavations and visited several rock art sites not currently shown to the public. In addition, several pedagogic activities (special visits, 'meet the archaeologist' activities, etc.) are undertaken, both during the school year and in holidays.

\section{Conservation of other archaeological sites in the PAVC}

There are other important archaeological sites in the Park and the surrounding area, apart from the rock art sites. Several research projects are under way to broaden our knowledge of the development of human settlement in the Côa Valley, from the Palaeolithic to the historic era. Among these are an investigation into the archaeological context of the Côa Valley Palaeolithic rock art (Aubry I998) and a study of the late prehistoric period (Carvalho I999). Sites are subject to similar documentation, conservation, and monitoring activities as the rock art sites, and the information is added to the Park archaeology database.

\section{Final considerations}

Since the preservation of Côa Valley rock art is a complex subject, with several interdependent dynamics, our approach does not aim to be definitive or absolute. While we try to consider holistically all the factors involved, there will inevitably be different kinds of constraints or developments that require readjustment or redefinition of the Conservation Programme. Similarly, we do not claim to have a complete understanding of the preservation needs of the rock art, for this is an adaptive essentially never-ending task.

All the monitoring actions described above need to be carried out over an extended time frame. This will enable an assessment of the changes in the biological, mechanical and geological dynamics of the engraved outcrops and surrounding area. Thus we must avoid the pursuit of instantaneous results. As Carrera Ramirez stated, referring to rock art conservation, the 'lack of immediate results and a certain dependence on political power has contributed to some scepticism regarding long-term projects' (2002). Recommending the implementation of working methods adapted to each specific situation, he highlights the importance of setting up 'complex, multifactorial schemes with non-automatic results' (Carrera Ramirez 2002).

We have taken this opportunity to present the PAVC Conservation Programme and to stress the primary concern of the Park: the development of an integrated and sustainable conservation and preservation policy. We close this article with words of optimism and warning. In spite of the poor condition of a few panels and outcrops, Côa rock art still has a long lifespan ahead, maybe as long as the most ancient art in the valley, some 25,000 years (Baptista 1999). In normal conditions (little human 
activity, rare earthquakes, etc.) the Côa rock art panels and outcrops are likely to survive for a very long time.

Nevertheless, despite different time-schemes (geological — prolonged; human brief), time, as Marguerite Yourcenar might have put it, is an all-sculpting chisel. Human beings have a limited lifespan - the traces that we leave behind, testimonies of our journey through history, will last considerably longer than any individual lifetime. Yet they are not eternal, and in due course 'planet earth' will dismantle them. This does not mean that all our efforts are useless, dispensable, or doomed. Within a human timescale it makes perfect sense to preserve the traces of our own history, this memory of what we are, want to be, and of the processes we employ to accomplish our ends. If these testimonies demonstrate our evolution, giving a meaning to this story that we tell ourselves about ourselves and providing an (illusory?) sense of depth and importance to our existence, they may well lead us to meditate on the relative weight of our brief human history when compared with that of the planet. Might this reflection lead us back to a lost humility and acceptance of the role and place of Sapiens sapiens in a global time and space: that transcends and stimulates us, that makes us transcend ourselves, but that also obliterates us? For it is this attitude that the Côa rock art illustrates so well, even though, paradoxically, it was created just at the dawn of our hegemonic appropriation of the planet ${ }^{2}$.

\section{Notes}

I A government body that, until its recent disbanding, was responsible for studying and documenting the corpus of Portuguese rock art.

2 This article was largely written in 2003 and updated for publication in CMAS. We recommend a visit to the PAVC's website (www.ipa.min-cultura.pt/coa): under Research, articles on the latest developments pertaining to the various Côa Valley are available for download. The English version of this paper was revised by Diana Silver.

\section{Bibliography}

Andersson, T I986 Preservation and restoration of rock carvings and rune-stones, in N S Brommelle and P Smith (eds) Case studies in the conservation of stone and wall paintings. London: The International Institute for Conservation of Historic and Artistic Works, I33-I 37

Aubry, T 1998 O povoamento Paleolítico da bacia do Baixo Côa, in A C P Lima (coord) Terras do Côa da Malcata ao Reboredo. Os valores do Côa. Guarda: Estrela-Côa - Agência de Desenvolvimento Territorial da Guarda, I84-189

Aubry, T, Calame, A, Chauvière, F-X, Dechanez, I, Sampaio, J and Tymula, S $200 \mathrm{I}$ Identification des processus d'évolution et de conservation des surfaces rocheuses gravées dans la Vallée du Côa a travers l'étude du site de Quinta da Barca Sul. Unpublished report for Instituto Português de Arqueologia — 200I

Aubry, T, Mangado Llach, X, Sampaio, J and Sellami, F 2002a Open-air rock-art and modes of exploitation during the Upper Palaeolithic in the Côa Valley (Portugal), Antiquity 76, 62-76

Aubry, T, Calame, A, Chauvière, F-X, Sampaio, J and Tymula, S 2002b Identification des processus d'évolution et de conservation des surfaces rocheuses gravées dans la Vallée du Côa a travers l'étude du Site de Quinta da Barca Sul. Unpublished report for Instituto Português de Arqueologia

Baptista, A M 1999 No tempo sem tempo: a arte dos caçadores paleoliticos do Vale do Côa. Com uma perspectiva dos ciclos rupestres pós-glaciares. Vila Nova de Foz Côa: Parque Arqueológico do Vale do Côa

Booth Childers, B 1994 Long-term lichen-removal experiments and petroglyph conservation: Freemont County, Wyoming, Ranch Petroglyph Site, Rock Art Research II(2), IOI-III

Cabral, J and Coelho, C (coords) 2002 Proposta de criação do Parque Arqueológico do Vale do Côa. Vila Nova de Foz Côa: IDAD and PAVC 
Carrera Ramírez, F 2002 La protección del arte prehistórico Ibérico, ¿Misión imposible? ArqueoWeb, 4(3). Available: http://www.ucm.es/info/arqueoweb/numero4_I/articulo4_3_proteccionarte.html [Accessed 29 December 2003]

Carvalho, A F 1999 Os sítios de Quebradas e de Quinta da Torrinha (Vila Nova de Foz Côa) e o Neolítico Antigo do Baixo Côa, Revista Portuguesa de Arqueologia, 2(I), 39-70

Devlet, E and Devlet, M 2002 Heritage protection and rock art regions in Russia, in L'art avant l'histoire. La conservation de l'art préhistorique. Io ${ }^{e s}$ journées d'études de la Section française de l'institut international de conservation. Paris: SFIIC, 87-94

Fernandes, A P B 2002 O Programa de Conservação do PAVC, in J Cabral and C Coelho (coords) Proposta de Criação do Parque Arqueológico do Vale do Côa. Vila Nova de Foz Côa: IDAD and PAVC, 82-86

Fernandes, A P B 2003 Visitor management and the preservation of rock art. Two case studies of open air rock art sites in Northeastern Portugal: Côa Valley and Mazouco, Conservation and Management of Archaeological Sites 6(2), 95-III

Finn, P and Hall, N 1996 Removal of iron fastenings and iron stains from sites in the Grampians, in A Thorn and J Brunet (eds) Preservation of rock art. Melbourne: Australian Rock Art Research Association, 65-7I

García Diez, M and Aubry, T 2002 Grafismo mueble en el Valle de Côa (Vila Nova de Foz Côa, Portugal): la estación arqueológica de Fariseu, Zephyrus 55, I57-I82

IGM and VISA 2000 Estudo integrado de exploração, impacte ambiental e recuperação paisagística para o núcleo de Pedreiras do Poio. Unpublished report for Instituto Português de Arqueologia, IGM and VISA

Instituto Nacional de Engenharia e Tecnologia Industrial (INETI) 200I Levantamento estereofotogramétrico de objectos - relatório final. Relatório final do trabalho desenvolvido no Parque Arqueológico do Vale do Côa. Unpublished report for Instituto Português de Arqueologia, INETI

Innes, J I985 Lichenometry, Progress in Physical Geography 9, I87-254

Jacobs, J and Gale, F 1994 Tourism and the protection of Aboriginal cultural sites. Canberra: Australian Government Publishing Services

Jordá Pardo, J F 1999 Geomorfología de la comarca de Santa María de Real de Nieva y el conjunto de Domingo García, in S Ripoll López and L J Municio González (eds) Domingo García - Arte Paleolítica al aire libre en la Meseta Castellana. Salamanca: Junta de Castilla y Léon and Universidad Nacional de Educación a Distancia, $25-30$

Kelly, R and McCarthy, D 200 I Effects of fire on rock art, American Indian Rock Art 27, I69-I76

Manning, S 2003 Fires damage rock art, Vestiges, monthly newsletter of URARA, Utah Rock Art Association 23(9), I4. Available: http://www.utahrockart.org/vestiges/archives/2003-09.pdf [Accessed II December 2003]

Martín Escorza, C 1999 Factores geológicos en los grabados rupestres de Domingo García, in S Ripoll López and L J Municio González (eds) Domingo García - Arte Paleolítica al aire libre en la Meseta Castellana. Salamanca: Junta de Castilla y Léon and Universidad Nacional de Educación a Distancia, 3 I-40

Oddy, A and Carroll, S (eds) I999 Reversibility — does it exist? London: British Museum

Pau-Preto, F and Luís, L 2003 Plano de ordenamento de parque arqueológico: uma nova figura de planeamento, Planeamento: Revista de Urbanismo e Ordenamento do Território I, 73-79

Pope, G A 2000 Weathering of petroglyphs: direct assessment and implications for dating methods, Antiquity 74, $833-843$

Price, C 1996 Stone conservation; an overview of current research. Los Angeles: Getty Conservation Institute

Ribeiro, M L 200 I Notícia explicativa da Carta Arqueológica Simplificada do Parque Arqueológico do Vale do Côa. Vila Nova de Foz Côa: Parque Arqueológico do Vale do Côa

Rodrigues, J D 1999 Conservação da arte rupestre do Parque Arqueológico do Vale do Côa. Unpublished report for Instituto Português de Arqueologia, Relatório 24I/99 - Gero, LNEC

Romão, P M S 1999 Colonização liquénica nas rochas xistosas do Parque Arqueológico do Vale do Côa. Unpublished report for Instituto Português de Arqueologia

Rosenfeld, A 1985 Rock art conservation in Australia. Canberra: Australian Government Publishing Service Stanley-Price, N 1996 Report to the Côa Valley Archaeological Park. Unpublished report for Instituto Português de Arqueologia

Stanley-Price, N, Rodrigues, J, Prudêncio, M, Wyrwoll, T, Sullivan, S and Padgett, A 1997 Relatório da Comissão Internacional de Conservação - Parque Arqueológico do Vale do Côa, Portugal. Unpublished report for Instituto Português de Arqueologia 
Swartz, B K 1997 An evaluation of rock art conservation practices at Foz Côa, Northern Portugal, Rock Art Research I4(I), 73-75

Vänskä, H $200 \mathrm{I}$ An evaluation of the role of lichens in the biodeterioration of rock surfaces with ancient petroglyphs (engravings) in the Côa Valley Archaeological Park in Portugal. Unpublished report for Instituto Português de Arqueologia

Walderhaug, O and Walderhaug, E M 1998 Weathering of Norwegian rock art - a critical review, Norwegian Archaeological Review 3I(2), II9-I39

Watchman, A I995 Recent petroglyphs, Foz Côa, Portugal, Rock Art Research I2(2), I04-Io8

Yourcencar, M no date O Tempo esse grande escultor. Lisboa: Difel

Zilhão, J I995 The age of the Côa valley (Portugal) rock-art: validation of archaeological dating to the Palaeolithic and refutation of 'scientific' dating to historic or proto-historic times, Antiquity 69, 883-90I

\section{Note on contributor}

The author graduated in archaeology from the University of Coimbra in I999. Since February 2000 he has been coordinating the Conservation Programme of Côa Valley Rock Art in the Côa Valley Archaeological Park. He has an MA in Managing Archaeological Sites from the Institute of Archaeology, University College London, and is currently undertaking a doctorate at the School of Conservation Sciences, Bournemouth University.

Correspondence to: Archaeologist, Côa Valley Archaeological Park (PAVC), PAVC - Av. Gago Coutinho, r9-A, 5150-6ro V. N. Foz Côa - Portugal. Email: abatarda.pavc@ipa.min-cultura.pt 